\title{
NACA wt Allele
}

National Cancer Institute

\section{Source}

National Cancer Institute. NACA wt Allele. NCI Thesaurus. Code C97654.

Human NACA wild-type allele is located within 12q23-q24.1 and is approximately $25 \mathrm{~kb}$ in length. This allele, which encodes nascent polypeptide-associated complex subunit alpha protein, is involved in the regulation of protein sorting. A point mutation in the gene may be associated with ovarian serous carcinoma. 